\title{
Phlebotomine sand flies in Southwest Germany: an update with records in new locations
}

Sandra Oerther ${ }^{1,2,3}$, Hanna Jöst ${ }^{4}$, Anna Heitmann ${ }^{4,5}$, Renke Lühken ${ }^{4,6}$, Andreas Krüger ${ }^{7}$, Irmgard Steinhausen $^{8}$, Christine Brinker ${ }^{4}$, Susanne Lorentz ${ }^{8}$, Michael Marx ${ }^{1}$, Jonas Schmidt-Chanasit ${ }^{4,6}$, Torsten Naucke ${ }^{8,9^{*}}$ and Norbert Becker ${ }^{2,3}$

\begin{abstract}
Background: Vector-borne diseases (VBD) are of growing global importance. Sand flies are potential vectors for phleboviruses (family Phenuiviridae) including Toscana virus (TOSV), Sicilian virus, Sandfly fever, Naples virus, and Leishmania parasites in Europe. To date, only two phlebotomine species have been recorded for Germany: Phlebotomus perniciosus and Phlebotomus mascittii. This study updates the distribution and abundance of the two occurring species.

Methods: An entomological field study was carried out during 2015-2018 to assess the abundance of sand flies in Southwest Germany within the federal states Baden-Wuerttemberg (BW) and Rhineland-Palatinate (RLP). A total of 176 collection sites were examined using CDC light traps.

Results: A total of 149 individuals of P. mascittii were collected. During 2015-2018, P. mascittii was found at all sites known positive from previous studies and was detected at 15 additional sites previously unknown for the presence of sand flies. Although the environment has changed considerably in 30 years, no significant difference in sand fly dynamics and distribution was found. Phlebotomus perniciosus has only been trapped once since 2001.

Conclusions: This study showed that sand flies occur in different areas in Southern Germany where they had not been recorded previously. Therefore, it can be assumed that they are more widespread than expected. In addition, sand flies could be found over several years at the same trapping sites, indicating population stability. This supports the need for continued surveillance of possible vector populations and urgent clarification of the vector competence of P. mascittii.
\end{abstract}

Keywords: Sand flies, Germany, Field study, Spatial distribution, Phlebotomus mascittii

\section{Background}

Sand flies (Diptera: Psychodidae: Phlebotominae) are insects with more than 1000 species worldwide. Species of the genus Phlebotomus are distributed in the Old World and species of Lutzomyia are distributed in the New World [1]. The vector group occurs throughout the

*Correspondence: tjnaucke@aol.com

${ }^{8}$ Parasitus Ex e.V., Niederkassel, Germany

Full list of author information is available at the end of the article tropics and sub-tropics, as well as in temperate zones. In Europe, sand flies are widespread in the Mediterranean area with about 25 species known to be present [2]. However, with increasing temperatures due to climate change, species such as Phlebotomus ariasi Tonnoir, 1921 and Phlebotomus perniciosus Newstead, 1911 are predicted to extend their range [3, 4].

In Germany, sand flies were detected for the first time in July 1999 during the first monitoring study in southwest Baden-Wuerttemberg (BW) [5]. Four specimens of 
Phlebotomus mascittii Grassi, 1908 were caught at three locations along the Upper Rhine Valley. In the following years the investigations were extended. By 2007, 237 specimens of $P$. mascittii had been found at 17 locations in different studies [6-8]. Additionally, in 2001, four specimens of the P. perniciosus were recorded for the first time in Germany and to our knowledge the species has never been trapped since then [8]. It seems that the collection sites of $P$. perniciosus and $P$. mascittii differ, since the trapping site of $P$. perniciosus was different from the locations where the $P$. mascittii specimen was caught in the latter study [8].

Sand flies in Germany are mostly active during the warm summer months, which is described in southern Switzerland, with climate conditions similar to those in the area investigated in the present study [9]. Female sand flies feed on different vertebrate hosts including humans, livestock, dogs, rodents, reptiles, amphibians and birds [10]. Host availability seems to be an important factor determining feeding behaviour. The main hosts of $P$. mascittii are dogs and humans, while $P$. perniciosus prefers dogs, humans, horses and rodents [11]. In addition, $P$. mascittii is known to also have an autogenous feeding behaviour, sucking on plant and fruit juices [12].

Phlebotomus perniciosus is a vector for parasitic protozoa (Leishmania spp.) [13] and viruses [14]. In Europe leishmaniasis is the most common sand fly-transmitted disease, caused by two parasites, Leishmania infantum and Leishmania tropica, causing visceral leishmaniasis and cutaneous leishmaniasis, respectively. In the Mediterranean basin, visceral leishmaniasis is the main form of disease, while cutaneous leishmaniasis arises periodically in Greece and surrounding countries [15]. In 2001, one case of human leishmaniasis was confirmed in Germany in a child that had no history of travel to known endemic areas [16]. One equine case [17] and several canine cases [18] have been described where the case history could indicate autochthonous infection within Germany, suggesting that infected sand flies must be present at least periodically. To date, $P$. mascittii has not yet been confirmed as a vector of leishmaniasis. Leishmania infantum was detected in a non-engorged female P. mascittii in Austria, close to the border of Slovakia [19]. On the island of Montecristo, Italy, Leishmania parasites could be found in rats in association with P. mascittii [20]. These findings suggest that $P$. mascittii could be relevant in leishmaniasis epidemiology.

Leishmania parasites are regularly imported by dogs and humans from endemic regions to Germany leading to a continual risk of autochthonous transmission [21]. Tourists return to Germany with infected dogs from the Mediterranean area and several animal welfare organizations support importing dogs from the Mediterranean region [6]. According to current estimates, there are already more than 100,000 leishmaniasis-positive dogs present in Germany [22]. However, the risk of human infection in Germany is still expected to be extremely low.

Sand flies are vectors for phleboviruses (family Phenuiviridae) including Sandfly fever Naples virus and Sandfly fever Sicilian virus. Sand fly-borne phleboviruses are widely distributed in the Mediterranean region and mainly cause mild disease characterized by fever, myalgia and headache. Several new phleboviruses have been detected in Europe in the last decade [23-26]. However, the medical and veterinary importance of these newly described viruses is yet to be investigated. To date there is no convincing evidence that a species of vertebrates is a natural reservoir of phleboviruses. The natural cycle of phleboviruses is poorly understood [27]. Neuroinvasive infections were reported for Sandfly fever Naples virus in Italy, Spain, Portugal and Cyprus [28, 29].

Case reports of seroepidemiological studies showed that the geographical distribution of Toscana virus is much wider than previously assumed and despite its importance as a human pathogen, it remains neglected and there are consequently many gaps of knowledge [30]. Especially during outdoor activities, the exposure to sand flies can increase the risk of an infection with phleboviruses [31].

In 2010, human Toscana virus infections were detected in $6.6 \%(n=150)$ of the cases diagnosed as meningitis or encephalitis of unknown aetiology in southern Germany [32].

In at least one of these cases, the affected individual had never left the area, so autochthonous transmission must be assumed [33].

Temperature plays an important role in the distribution of sand fly species and global warming will lead to an extension of the distributional area and thereby also to an increase in the risk of sand fly-borne infections [34]. Since 2008, no active field work has been carried out in Southwest Germany. Therefore, the here presented field study aimed to collect new data about the current distribution, occurrence and abundance of sand flies in this area.

\section{Methods}

\section{Study area and survey}

A longitudinal study on the distribution of sand flies along the Upper Rhine Valley was carried out in the federal states Baden-Wuerttemberg (BW) and RhinelandPalatinate (RLP) between 11th and 21st August 2015 and during June-September 2016-2018 (Fig. 1). The number of trap nights was 108, 74, 415 and 272 in the years 
2015-2018, respectively. In 2015, based on previously known sites with established sand fly populations, six collection sites were chosen. Two of these were entirely new sites, selected in close proximity to 4 other known sites. In the following years, the selection of sites was done according to the following two conditions: sites already studied in previous studies, and newly selected sites with potentially favourable environmental and climatic conditions, i.e. having three consecutive nights with a minimum temperature of $15{ }^{\circ} \mathrm{C}$. In order to find new locations, citizens were informed about the study with an information flyer. In addition, local health authorities and municipalities were informed, and advertisements made in local newspapers. Citizens were asked to report potential sand fly trapping sites, the required conditions of which were described in the flyer.

All locations were properly inspected, and habitat types were identified (animal shelters, farms, old quarries, caves) according to standard protocols [35]. In 2017, the area was extended to RLP, the area where $P$. perniciosus was trapped in 2001. In 2018, only positive sites were sampled with increased frequency, with the intent to catch higher numbers of sand flies for pathogen screening. Temperature data from the study area were collected from the German Meteorological Service (DWD) [36]. Mean annual climatic characteristics from 2015 to 2018 of both study areas can be summarized as follows: annual minimum temperatures of $-13.9^{\circ} \mathrm{C}$, annual maximum temperatures of $35^{\circ} \mathrm{C}$, mean summer temperature of $21.5^{\circ} \mathrm{C}$ (June to September), summer precipitation of 200-250 mm [36].

\section{Sand fly sampling}

Collection was done with Center for Disease Control and Prevention miniature light traps (CDC miniature light traps 512, Bioquip, CA, USA). Depending on the size of the collection site 1 to 5 CDC traps were deployed with a distance of about $5 \mathrm{~m}$ from each other and operated between 18:00 $\mathrm{h}$ and 8:00 $\mathrm{h}$. Traps were predominantly placed inside barns, close to the ground or walls with or without organic material at a height of 1-1.5 m. The placement of the traps was selected according to previously described habitat preferences of sand flies [6]: old barns with non-concrete ground, brick or mud walls, often abandoned and sheltered from wind [5]. Global positioning system (GPS) coordinates and environmental descriptions were recorded on site. In 2018, temperature and humidity were recorded in both study regions (BW and RLP) with Hobo Pro v2 data loggers at 12 different locations (Additional file 1: Table S1) from June to the end of September (Onset, MA, USA). In each state, 6 sites were chosen, according to the highest capture rate. Depending on the capture rate, collections were repeated up to 9 times during one season, with the aim of capturing high numbers of sand flies (Additional file 1 : Table S1). Captured insects were immediately stored in a polystyrene box with cool packs and manually inspected on a sheet of white paper to eliminate bycatch. Afterwards, sand flies were preserved in $100 \%$ ethanol and kept in $1.5 \mathrm{ml}$ reagent tubes. A sand fly trapping factor (number of sand flies/trap-night) was calculated to compare the numbers of sand flies trapped at each collection site. Trap-nights are defined as the number of sampling nights multiplied with the number of traps per site.

\section{Molecular identification and pathogen screening}

Each specimen was processed individually. Deoxyribonucleic acid (DNA) and ribonucleic acid (RNA) was extracted with a KingFisher ${ }^{\mathrm{TM}}$ Flex Magnetic Particle Processor using MagMAX ${ }^{\mathrm{TM}}$ Pathogen ribonucleic acid/DNA Kit (Thermo Fisher Scientific, Waltham, MA, USA). Morphological identification of sand fly species was confirmed by DNA barcoding analysis of the cytochrome $c$ oxidase subunit $1(\operatorname{cox} 1)$ as described by Polseela et al. [37]. Polymerase chain reaction (PCR) products were subjected to Sanger sequencing. The resulting sequences were submitted for species identification using the basic alignment search tool (BLAST) in the GenBank DNA sequence databases (https://blast.ncbi.nlm.nih.gov/). For virus screening, extracted RNA samples were tested by pan-phlebovirus [38] and pan-flavivirus PCR [39].

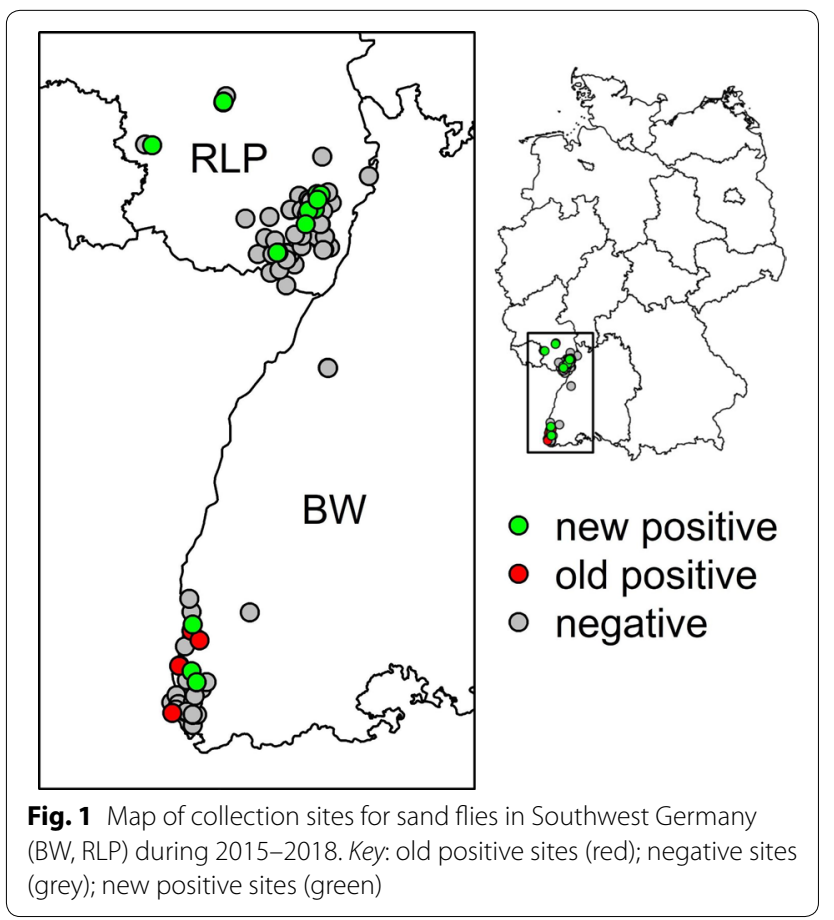


In 2018, the 81 specimens were screened on Leishmania parasites with a quantitative polymerase chain reaction (qPCR) using the primers OWLeishkDNAfwd* (3'-GCT TTA GTG GGT TGG AGC CT-5'), OWLeishkDNArev* (3'-TCA ACC CAA GAC CAC CAT CG-5') and OWLeishkDNAProbe*: (6FAM)CGG GTG TCT TTG ATG ATG CTG GGG TGG GT(BHQ1) [40]. The qPCR was performed with the SensiFAST ${ }^{\mathrm{TM}}$ Probe NoROX Kit (Bioline) with $10 \mu \mathrm{l}$ Master Mix Bioline $(2 \times)$, $0.3 \mu \mathrm{l}$ of each primer $(900 \mathrm{nM}), 0.5 \mu \mathrm{l}$ probe $(200 \mathrm{nM})$, $1.2 \mu \mathrm{MgCl}_{2}(25 \mathrm{mM}), 1.7 \mu \mathrm{l}$ distilled water and $6 \mu \mathrm{l}$ DNA template. The reaction was conducted with denaturation for $5 \mathrm{~min}$ at $95^{\circ} \mathrm{C}$ followed by 37 cycles at $95^{\circ} \mathrm{C}$ for $10 \mathrm{~s}$, $57.5-66.0^{\circ} \mathrm{C}$ for $40 \mathrm{~s}$ (touchdown $0.5^{\circ} \mathrm{C}$ for 17 cycles) and a final elongation for $30 \mathrm{~s}$ at $40{ }^{\circ} \mathrm{C}$. As a positive control, genomic DNA isolated from one sand fly (P. perniciosus) with added 200 Leishmania infantum strain 3511 parasites was used. The detection minimum for the parasite was determined as $50 \mathrm{~L}$. infantum parasites per sand fly.

\section{Results}

During 2015-2018, a total of 149 (92 female and 57 male) sand flies were collected at 37 (21\%) out of 176 collection sites (Table 1). The earliest trap night was on the 30th June and the latest trap night on the 21th September. The earliest capture of sand flies during the entire study period was on the 3rd of July 2018 and the latest on the 31th of August 2017 (Additional file 1: Table S1). All sand fly specimens were identified as $P$. mascittii by morphology and barcoding of the cox 1 gene fragment. None of the trapped sand flies were engorged.

The sand fly trapping factor over the entire sampling period indicates that 0.17 sand flies were caught per trap on average. The highest trapping factor was found for the year 2018 with 0.3 sand flies per trap. In 2015, 16 specimens ( 7 male and 9 female) of $P$. mascittii were caught at $5(83.3 \%)$ out of 6 sampling sites in BW. Two new collection sites were identified in this year. In summer 2016, no sand flies were recorded at 36 new, previously uninvestigated collection sites. In 2017, 52 P. mascittii (22 male and 30 female) were captured. Out of 100 collection sites, 17 (17\%) were positive for phlebotomine sand flies. Two new sites in the federal state BW and 10 new sites for the federal state RLP were identified. In addition, 5 previously known collection sites for $P$. mascittii for BW were confirmed. In 2018, 81 P. mascittii (28 male and 53 female) were trapped. Out of 34 collection sites, 15 (44\%) were confirmed positive. One new collection site was found positive for RLP. Within the duration of the study, 15 new sites infested with sand flies were identified.

Overall, the percentage of females was $60.3 \%$. Only in July 2017, the percentage of males was higher at $54.2 \%$.
In other months the percentage of females was between $56.2-67.9 \%$.

From late August, the number of sand flies captured decreased, until early September, where none were captured. It was observed that the number of sand flies decreased after several sampling nights at a collection site, especially at sites with high sand fly trapping numbers (Additional file 1: Table S1).

The mean temperature of the months July and August in $2015,2016,2017$ and 2018 was $22.9{ }^{\circ} \mathrm{C}, 21.4{ }^{\circ} \mathrm{C}$, $21.3{ }^{\circ} \mathrm{C}$ and $23.1{ }^{\circ} \mathrm{C}$, respectively. In July 2018,18 days were hot days with temperatures above $30{ }^{\circ} \mathrm{C}$. The month with the fewest hot days was August 2016 with 7 hot days (Fig. 2). Temperatures and relative humidity recorded from the data logger in 2018 were analyzed. At Bremgarten, a site where sand flies were caught regularly, temperatures on the trapping days at 19:00 $\mathrm{h}$ ranged from $27.7{ }^{\circ} \mathrm{C}$ to $30.8{ }^{\circ} \mathrm{C}$ with a relative humidity between $35.8-48.3 \%$. Sites negative for sand flies did not differ significantly in humidity and temperature.

The most common trapping sites were old, natural barns, especially those with non-concrete soil, in the immediate vicinity of humans and animals such as dogs, cats, rats, horses, chickens and lizards. They were close to human dwellings and generally characterized by old, uneven, and cracked brick walls with moist soil and tamped clay. In addition to this, they were often quiet and abandoned. Six P. mascittii were found in a sylvatic site named "Isteiner Klotz". Seven other sylvatic sites (caves in forestry areas) were investigated in 2017 but they were all negative for the presence of sand flies.

All sand flies tested negative for phleboviruses, flaviviruses and Leishmania spp. infection.

\section{Discussion}

In this study, sand flies were trapped at 37 out of the 176 sites in Southwest Germany. This shows that these potential vectors are more widespread than previously known. However, non-detection of sand flies at a trap site should be interpreted with caution and not taken immediately as evidence of a lack of a population there. Sites which had regularly been positive in previous studies were positive for sand flies again, demonstrating stable populations at these sites. The number of trapped sand flies was always very small, usually only 1 or 2 specimens. In most studies, P. mascittii is found in low population densities [41-44]. The low density may be due to the specific ecological niche they are adapted to (caves, tunnels and natural barns) [41, 45]. Generally, CDC light traps are used to determine relative changes in abundance over time and space [46], but for species like $P$. mascittii capture methods have to be adapted as they are probably less attracted by light and carbon dioxide [9]. It is even suspected that 
Table 1 Prevalence of sand flies from collection sites in Southwest Germany during 2015-2018

\begin{tabular}{lllllll}
\hline Year & Trapping period & $\begin{array}{l}\text { No. of collection } \\
\text { sites }\end{array}$ & $\begin{array}{l}\text { No. of sampling } \\
\text { nights }\end{array}$ & $\begin{array}{l}\text { No. of trap } \\
\text { nights }\end{array}$ & $\begin{array}{l}\text { No. of collected sand flies } \\
\text { (female/male) }\end{array}$ & $\begin{array}{l}\text { Sand fly } \\
\text { trapping } \\
\text { factor }\end{array}$ \\
\hline 2015 & 11-21 August & 6 & 8 & 108 & $16(9 / 7)$ & 0.15 \\
2016 & 22 July to 29 August & 36 & 9 & 74 & 0 & 0 \\
2017 & 18 July to 31 August & 100 & 31 & 415 & $52(30 / 22)$ & 0.13 \\
2018 & 29 June to 21 September & 34 & 31 & 272 & $81(53 / 28)$ & 0.30 \\
Total & & 176 & 79 & 869 & $149(92 / 57)$ & 0.17 \\
\hline
\end{tabular}

P. mascittii is "light-shy" and that the catches are possibly only random catches [47]. In addition, using pieces of fruit as further attractants for $P$. mascittii has been suggested by Poeppl et al. [48] as a way to increase trapping effectiveness. In order to make precise predictions about the distribution of sand flies in Germany, trapping must be extended to other areas using different methods.

Phlebotomus mascittii is widely distributed in central Europe and can be found north of the Alps in countries like France [41], Switzerland [9] and Belgium [49]. In Germany, this species was found in the states of BW and RLP, while in other regions no sand flies have been detected to date. The state of Bavaria in Southern Germany was investigated in previous studies for sand fly presence, but negative for sand flies. Furthermore, since the first detection of $P$. mascittii in Germany, CDC traps for sand fly trapping were placed sporadically along the Rhine plane in the state North Rhine Westphalia (NRW) up to Duesseldorf over the past 20 years but have thus far been negative for sand flies (TN).

With the assumption that sand flies are remnants of the Holocene, they have survived in small refugial areas and probably could be found in other regions of Germany. With global warming and climate change they might expand their range and disperse to areas where suitable habitats are available [3]. Generally, sand flies require a temperature of at least $20^{\circ} \mathrm{C}$ during the warmest month and an annual mean temperature of $10{ }^{\circ} \mathrm{C}[50,51]$. Consequently the $10{ }^{\circ} \mathrm{C}$-annual-isotherm is regarded as the northern boundary for sand fly distribution, which has

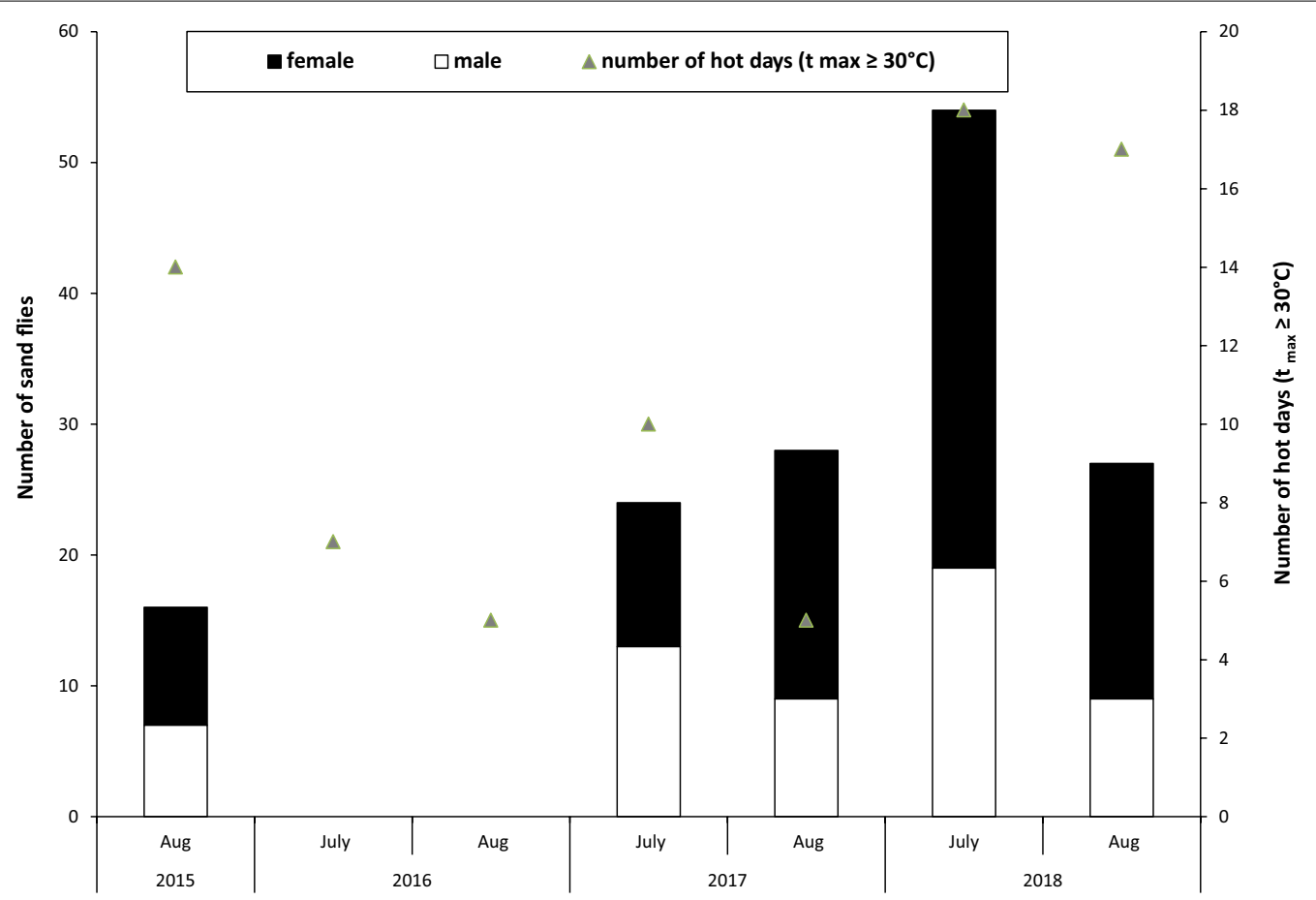

Fig. 2 Number of sand flies collected in Southwest Germany during $2015-2018$ and number of hot days $\left(t_{\max } \geq 30^{\circ} \mathrm{C}\right)$ (triangles) 
already shifted north in the last decades [34]. During the study period, monthly mean temperatures were between $21.3^{\circ} \mathrm{C}$ and $22.9^{\circ} \mathrm{C}$. Therefore, temperatures could probably not explain the negative trapping results in 2016 . However, there were fewer hot days $\left(\operatorname{tmax} \geq 30{ }^{\circ} \mathrm{C}\right)$ and more periods with rain in 2016 compared to the other years. Rainfall reduces the amount of suitable diurnal resting sites for the adult insects and limits the adult flight activity, leading to lowered trapping success [52]. The deviating weather conditions could also have led to smaller population densities. Many obscure factors such as sferics, humidity, air pressure changes, and other weather phenomena likely have an impact on sand fly abundance [53]. Even some trap sites where sand flies were caught regularly in previous years were negative.

Results from France and Switzerland suggest that $P$. mascittii only undergoes one generation per year in temperate regions [9]. This has previously been shown for Germany [54]. Generally, sand flies have a longevity of 7 to 10 weeks, with cooler temperatures leading to decreased longevity [7]. Our data suggest that only one generation is developing, as the number of trapped sand flies decreased at the end of August (Additional file 1: Table S1). The number of females captured in our study was higher on average than the number of males; this could be seen also in other studies $[2,8]$. Under laboratory conditions the proportion of males to females is 50:50 [7]. Females are probably more attracted by the $\mathrm{CO}_{2}$ as they search for a host or breeding site. In addition, compared to females, males have reduced flight activity and spend more time resting. This phenomenon reduces the likelihood of male sand flies being caught in a trap.

Remarkable was the finding of six individuals within the only known sylvatic site named "Isteiner Klotz" in 2018. For 17 years, no sand flies had been detected there, despite trapping occurring on several occasions. The site lies within a forest and sand flies were caught in a small cave within a rocky outcrop. Several sylvatic sites similar to the "Isteiner Klotz" were investigated in 2017. No further sites were positive for sand flies. Outside Germany, P. mascittii is known to be found in such ecological niches, where temperature and humidity remain more constant than in open environments [45].

Pathogens transmitted by phlebotomine sand flies are already present in Germany and transmission of Leishmania parasites and phleboviruses has been suspected $[17,33]$. To date it has not been proven that $P$. mascittii is a vector for Leishmania parasites. Leishmania infantum has been detected in P. mascittii, but transmission could not be confirmed (TN, unpublished data). There are few studies on the vector competence of sand flies as their colonisation is difficult $[55,56]$. Nevertheless, several criteria for the possible vector capacity of $P$. mascittii are fulfilled, such as anthropophilic behaviour and feeding on reservoir hosts. More than 100,000 Leishmania-infected dogs are currently living in Germany and the number of dogs imported to Germany from endemic areas is growing, leading to an increase in cases of leishmaniasis [23]. The risk for a human autochthonous Leishmania infection [47] or the formation of Leishmania cycles in Germany is so far very low. In addition, sand flies tested in our study were all negative for phleboviruses and flaviviruses. However, the low number of sand flies tested does not rule out circulation of these viruses in Southwest Germany [17]. Further studies are required to evaluate if these pathogens circulate in the sand fly populations in Germany. This situation might change in future if sand fly species expand in range due to climate change and build up larger populations [30]. In addition, further studies are necessary to clearly characterize the environmental conditions of the habitats of $P$. mascittii.

\section{Conclusions}

The study results reveal that sand flies occur in different areas where they have not been detected before. During the study, 15 new sites in Southwest Germany were identified as positive. The most common biotopes were old barns, especially with non-concrete ground, and close to humans and animals. Generally, it appears that these sand flies are associated with a relatively stable and calm environment. The occurrence of phlebotomine sand flies in Southwest Germany is expected to be larger than the number of collected specimens suggests. This reinforces the need for further surveillance in suitable regions in Germany. Furthermore, there is an urgent need to clarify the vector competence and capacity of $P$. mascittii. Global warming might lead to an extension of the distributional area of sand flies and therefore an increase in the risk for sand fly-borne infections in Southwest Germany.

\section{Supplementary information}

Supplementary information accompanies this paper at https://doi. org/10.1186/s13071-020-04058-6.

Additional file 1: Table S1. Collection sites, date of collection and number of captured Ph. mascittii (male ( $\mathrm{m}$ ) and female (f)) of the entomological field study in Southwest Germany during $2015-2018\left({ }^{*}\right.$ collection sites with data logger in 2018).

\section{Abbreviations}

BW: Baden-Wuerttemberg; CDC: Center for Disease Control and Prevention; cox1: cytochrome c oxidase subunit 1 gene; DNA: deoxyribonucleic acid; GFS e.V:: Gesellschaft zur Förderung der Stechmückenbekämpfung e.V; GPS: global positioning system; NRW: North Rhine Westphalia; PCR: polymerase chain reaction; qPCR: quantitative polymerase chain reaction; $R N A$ : ribonucleic acid; RLP: Rhineland-Palatinate; TOSV: Toscana virus; VBD: vector-borne disease. 


\section{Acknowledgements}

We thank Michelle Helms for excellent technical assistance and Professor Stefanie Becker for the initial input of her expertise in this field. Furthermore, we would like to thank the Klaus Tschira Foundation with special regards for their support. Publication of this paper has been sponsored by Bayer Animal Health in the framework of the 15th CVBD World Forum Symposium.

\section{Authors' contributions}

$\mathrm{SO}, \mathrm{HJ}, \mathrm{AH}, \mathrm{RL}, \mathrm{IS}, \mathrm{SL}, \mathrm{TN}, \mathrm{JCS}, \mathrm{NB}$ and MM conceived and designed the study. SO, IS and AH collected the data. SO, HJ, RL, AH, AK and TN analyzed the data. $\mathrm{CB}$ and $\mathrm{AH}$ designed the Leishmania $\mathrm{qPCR}$. SO, HJ, RL and $\mathrm{AH}$ drafted the manuscript. NB and JSC critically revised the manuscript. All authors read and approved the final manuscript.

\section{Funding}

This research was supported by a grant of the Klaus Tschira Foundation (Grant number 00.309.2016), the German Federal Ministry for the Environment, Nature Conservation, Building and Nuclear Safety (BMUB) through the Federal Environment Agency (UBA) (Grant number FKZ 371748432 0) and the Gesellschaft zur Förderung der Stechmückenbekämpfung e.V. (GFS e.V.).

\section{Availability of data and materials}

Data supporting the conclusions of this article are included within the article and its additional file.

\section{Ethics approval and consent to participate}

Not applicable.

\section{Consent for publication}

Not applicable.

\section{Competing interests}

The authors declare that they have no competing interests.

\section{Author details}

${ }^{1}$ Institute of Global Health, Heidelberg University, Heidelberg, Germany.

${ }^{2}$ German Mosquito Control Association (KABS), Speyer, Germany. ${ }^{3}$ Institute for Dipterology (IfD), Speyer, Germany. ${ }^{4}$ Bernhard-Nocht-Institute for Tropical Medicine, Hamburg, Germany. ${ }^{5}$ Friedrich-Loeffler-Institut, Federal Research Institute for Animal Health, Greifswald-Insel Riems, Germany. ${ }^{6}$ Faculty of Mathematics, Informatics and Natural Sciences, University Hamburg, Hamburg, Germany. ${ }^{7}$ Bundeswehr Hospital Hamburg-Branch Tropical Microbiology \& Entomology, Hamburg, Germany. ${ }^{8}$ Parasitus Ex e.V., Niederkassel, Germany. ${ }^{9}$ Laboklin GmbH \& Co. KG, Bad Kissingen, Germany.

Received: 17 December 2019 Accepted: 1 April 2020 Published online: 21 April 2020

\section{References}

1. Berenger J-M, Parola P. Arthropod vectors of medical importance. In: Cohen J, Powderly W, Opal S, editors. Infectious diseases. Amsterdam: Elsevier Ltd.; 2016. p. 104-12.

2. Cazan CD, Păstrav IR, lonică AM, Oguz G, Kasap OE, Dvorak V, et al. Updates on the distribution and diversity of sand flies (Diptera: Psychodidae) in Romania. Parasites Vectors. 2019;12:247.

3. Fischer D, Thomas SM, Beierkuhnlein C. Temperature-derived potential for the establishment of phlebotomine sandflies and visceral leishmaniasis in Germany. Geospat Health. 2010;5:56-69.

4. Gálvez R, Descalzo MA, Guerrero I, Miró G, Molina R. Mapping the current distribution and predicted spread of the leishmaniosis sand fly vector in the Madrid region (Spain) based on environmental variables and expected climate change. Vector Borne Zoonotic Dis. 2011;11:799-806.

5. Naucke T, Pesson B. Presence of Phlebotomus (Transphlebotomus) mascittii Grassi, 1908 (Diptera: Psychodidae) in Germany. Parasitol Res. 2000:86:335-6.

6. Naucke T, Menn B, Massberg D, Lorentz S. Sandflies and leishmaniasis in Germany. Parasitol Res. 2008;103:65-8.
7. Steinhausen I. Untersuchung zur Verbreitung von Sandmücken (Phlebotomen) in Deutschland mit Hilfe geographischer Informationssysteme (GIS). Institute of Medical Parasitology, Bonn, Germany; 2005. https://www.parasitosen.de/images/downloads/publikationen/diplo marbeit_irmgard_steinhausen.pdf. Accessed 20 Feb 2020.

8. Naucke TJ, Schmitt C. Is leishmaniasis becoming endemic in Germany? Int J Med Microbiol. 2004;293(Suppl. 37):179-81.

9. Grimm F, Gessler M, Jenni L. Aspects of sandfly biology in southern Switzerland. Med Vet Entomol. 1993:7:170-6.

10. Alexander B. Sampling methods for phlebotomine sandflies. Med Vet Entomol. 2000;14:109-22.

11. Bongiorno G, Habluetzel A, Khoury C, Maroli M. Host preferences of phlebotomine sand flies at a hypoendemic focus of canine leishmaniasis in central Italy. Acta Trop. 2003;88:109-16.

12. Ready PD, Ready PA. Prevalance of Phlebotomus spp. in southern France: sampling bias due to different man-biting habits and autogeny. Ann Trop Med Parasitol. 1981;75:475-6.

13. Remadi L, Jiménez $M$, Chargui $N$, Haouas $N$, Babba H, Molina R. The vector competence of Phlebotomus perniciosus for Leishmania infantum zymodemes of Tunisia. Parasitol Res. 2018;117:2499-506.

14. Depaquit J, Grandadam M, Fouque F, Andry P, Peyrefitte C. Arthropodborne viruses transmitted by phlebotomine sandflies in Europe: a review. Euro Surveillance. 2010;15:19507.

15. Semenza JC, Suk JE. Vector-borne diseases and climate change: a European perspective. FEMS Microbiol Lett. 2018;365:fn×244.

16. Bogdan C, Schönian G, Banuls A-L, Hide M, Pratlong F, Lorenz E, et al. Visceral leishmaniasis in a German child who had never entered a known endemic area: case report and review of the literature. Clin Infect Dis. 2001;32:302-6.

17. Koehler K, Stechele M, Hetzel U, Domingo M, Schönian G, Zahner H, et al. Cutaneous leishmaniosis in a horse in southern Germany caused by Leishmania infantum. Vet Parasitol. 2002;109:9-17.

18. Mencke $\mathrm{N}$. The importance of canine leishmaniosis in non-endemic areas, with special emphasis on the situation in Germany. Berl Munch Tierarztl Wochenschr. 2011;124:434-42.

19. Obwaller AG, Karakus M, Poeppl W, Töz S, Özbel Y, Aspöck H, et al. Could Phlebotomus mascittii play a role as a natural vector for Leishmania infantum? New data. Parasites Vectors. 2016;9:458.

20. Zanet S, Sposimo P, Trisciuoglio A, Giannini F, Strumia F, Ferroglio E. Epidemiology of Leishmania infantum, Toxoplasma gondii, and Neospora caninum in Rattus rattus in absence of domestic reservoir and definitive hosts. Vet Parasitol. 2014;199:247-9.

21. Ready P. Leishmaniasis emergence in Europe. Euro Surveillance. 2010:15:19505.

22. Naucke T. Leishmaniose-Infektionen in Deutschland - Gefahr geht nicht nur von Sandmücken aus. Tierärztl Umsch. 2016:71:130.

23. Calzolari M, Chiapponi C, Bellini R, Bonilauri P, Lelli D, Moreno A, et al. Isolation of three novel reassortant phleboviruses, Ponticelli I, II, III, and of Toscana virus from field-collected sand flies in Italy. Parasites Vectors. 2018;11:84.

24. Remoli ME, Jiménez M, Fortuna $C$, Benedetti $E$, Marchi $A$, Genovese $D$, et al. Phleboviruses detection in Phlebotomus perniciosus from a human leishmaniasis focus in South-West Madrid region, Spain. Parasites Vectors. 2016;9:205.

25. Charrel RN, Moureau G, Temmam S, Izri A, Marty P, Parola P, et al. Massilia virus, a novel Phlebovirus (Bunyaviridae) isolated from sandflies in the Mediterranean. Vector Borne Zoonotic Dis. 2009:9:519-30.

26. Amaro F, Zé-Zé L, Alves MJ, Börstler J, Clos J, Lorenzen S, et al. Co-circulation of a novel phlebovirus and Massilia virus in sandflies, Portugal. Virol J. 2015;12:174.

27. Jancarova M, Bichaud L, Hlavacova J, Priet S, Ayhan N, Spitzova T, et al. Experimental infection of sand flies by Massilia virus and viral transmission by co-feeding on sugar meal. Viruses. 2019;11:332.

28. Cusi MG, Savellini GG, Zanelli G. Toscana virus epidemiology: from Italy to beyond. Open Virol J. 2010;4:22.

29. Alkan C, Bichaud L, de Lamballerie X, Alten B, Gould EA, Charrel RN. Sandfly-borne phleboviruses of Eurasia and Africa: epidemiology, genetic diversity, geographic range, control measures. Antivir Res. 2013;100:54-74.

30. Ayhan N, Prudhomme J, Laroche L, Bañuls A-L, Charrel RN. Broader geographical distribution of Toscana virus in the Mediterranean region 
suggests the existence of larger varieties of sand fly vectors. Microorganisms. 2020;8:114.

31. Kniha E, Obwaller AG, Dobler G, Poeppl W, Mooseder G, Walochnik J. Phlebovirus seroprevalence in Austrian Army personnel returning from missions abroad. Parasites Vectors. 2019;12:416.

32. Kimmig P, Pluta S, Hartelt K, Naucke T, Oehme R, Mackenstedt U. Klimawandel und die Ausbreitung von vektorübertragenen Infektionskrankheiten. Tierseuchen und Zoonosen. 2010;17(2):109-15.

33. Meyer-König U, Schneider S, Özdemir S, Hutmacher K, Weidmann M, Kaiser $\mathrm{R}$, et al. Toscana virus associated encephalitis is emerging north of the Alps. In: National symposium on zoonoses research, 7-8 October 2010, Berlin, Germany. 2010.

34. Fischer D, Moeller P, Thomas SM, Naucke TJ, Beierkuhnlein C. Combining climatic projections and dispersal ability: a method for estimating the responses of sandfly vector species to climate change. PLoS Negl Trop Dis. 2011;5:e1407.

35. Medlock J, Balenghien T, Alten B, Versteirt V, Schaffner F. Field sampling methods for mosquitoes, sandflies, biting midges and ticks: VectorNet project 2014-2018. EFSA Supporting Publications. 2018;15:1435E. https ://www.ecdc.europa.eu/sites/default/files/documents/Nector-samplingfield-protocol-2018.pdf. Accessed 20 Feb 2020.

36. Deutscher Wetterdienst (DWD). 2019. https://www.dwd.de/DE/klima umwelt/klimaueberwachung/deutschland/deutschland_node.html. Accessed 27 June 2019

37. Polseela R, Jaturas N, Thanwisai A, Sing K-W, Wilson J-J. Towards monitoring the sandflies (Diptera: Psychodidae) of Thailand: DNA barcoding the sandflies of Wihan Cave, Uttaradit. Mitochondrial DNA A. 2016;27:3795-801.

38. Lambert AJ, Lanciotti RS. Consensus amplification and novel multiplex sequencing method for $S$ segment species identification of 47 viruses of the Orthobunyavirus, Phlebovirus, and Nairovirus genera of the family Bunyaviridae. J Clin Microbiol. 2009;47:2398-404.

39. Chao DY, Davis BS, Chang GJ. Development of multiplex real-time reverse transcriptase PCR assays for detecting eight medically important flaviviruses in mosquitoes. J Clin Microbiol. 2007:45:584-9.

40. Bifeld E, Nevado PT, Bartsch J, Eick J, Clos J. A versatile qPCR assay to quantify trypanosomatidic infections of host cells and tissues. Med Microbiol Immunol. 2016:205:449-58.

41. Prudhomme J, Rahola N, Toty C, Cassan C, Roiz D, Vergnes B, et al. Ecology and spatiotemporal dynamics of sandflies in the Mediterranean Languedoc region (Roquedur area, Gard, France). Parasites Vectors. 2015;8:642.

42. Khoury C, Cavallini C, Miceli N, Maroli M. Distribution and relative density of phlebotomine sandflies (Diptera: Psychodidae) in Rome, Italy. Ann Parasitol Hum Comp. 1992;67:151-4.

43. Gordon Smith C, Maroli M, Bettini S. Leishmaniasis in Tuscany (Italy): (I) an investigation on phlebotomine sandflies in Grosseto Province. Trans R Soc Trop Med Hyg. 1977;71:315-21.

44. Veronesi E, Pilani R, Carrieri M, Bellini R. Trapping sand flies (Diptera: Psychodidae) in the Emilia-Romagna region of northern Italy. J Vector Ecol. 2007;32:313-8.
45. Naucke T, Menn B, Massberg D, Lorentz S. Winter activity of Phlebotomus (Transphlebotomus) mascittii, Grassi 1908 (Diptera: Psychodidae) on the island of Corsica. Parasitol Res. 2008:103:477.

46. Alten B, Ozbel Y, Ergunay K, Kasap OE, Cull B, Antoniou M, et al. Sampling strategies for phlebotomine sand flies (Diptera: Psychodidae) in Europe. Bull Entomol Res. 2015;105:664-78.

47. Lozan J, Garms R, Naucke T. Die Leishmaniose-eine potenzielle Gefahr in Mitteleuropa. Warnsignal Klima: Gesundheitsrisiken-Gefahren für Menschen, Tiere und Pflanzen Hamburg: Gruner und Jahr (GEO Magazin), 2nd edn, Chapter: 3.2.11:211-4; 2008.

48. Poeppl W, Obwaller AG, Weiler M, Burgmann H, Mooseder G, Lorentz S, et al. Emergence of sandflies (Phlebotominae) in Austria, a Central European country. Parasitol Res. 2013;112:4231-7.

49. Depaquit J, Naucke TJ, Schmitt C, Ferté H, Léger N. A molecular analysis of the subgenus Transphlebotomus Artemiev, 1984 (Phlebotomus, Diptera, Psychodidae) inferred from ND4 mtDNA with new northern records of Phlebotomus mascittii Grassi, 1908. Parasitol Res. 2005;95:113-6.

50. WHO. The leishmaniases: report of a WHO expert committee [meeting held in Geneva from 10 to 16 November 1982]. Geneva: World Health Organization; 1984. https://apps.who.int/iris/handle/10665/38742. Accessed 20 Feb 2020.

51. Naucke T. Leishmaniose-Einzug in Deutschland. Tierärztl Umsch. 2007:62:495-500.

52. Simsek FM, Alten B, Caglar SS, Ozbel Y, Aytekin AM, Kaynas S, et al. Distribution and altitudinal structuring of phlebotomine sand flies (Diptera: Psychodidae) in southern Anatolia, Turkey: their relation to human cutaneous leishmaniasis. J Vector Ecol. 2007;32:269-79.

53. Tichy H, Kallina W. Insect hygroreceptor responses to continuous changes in humidity and air pressure. J Neurophysiol. 2010;103:3274-86.

54. Schmitt C. Untersuchungen zur Biologie und Verbreitung von Phlebotomus (Transphlebotomus) mascittii, Grassi 1908) (Diptera: Psychodidae) in Deutschland. Diplome, Institute of Medical Parasitology: Bonn; 2002. https://parasitosen.de/images/downloads/publikationen/Diplomarbe it_Schmitt.pdf. Accessed 20 Feb 2020.

55. Volf P, Volfova V. Establishment and maintenance of sand fly colonies. J Vector Ecol. 2011;36:S1-9.

56. Bates PA. Transmission of Leishmania metacyclic promastigotes by phlebotomine sand flies. Int J Parasitol. 2007:37:1097-106.

\section{Publisher's Note}

Springer Nature remains neutral with regard to jurisdictional claims in published maps and institutional affiliations.
Ready to submit your research? Choose BMC and benefit from:

- fast, convenient online submission

- thorough peer review by experienced researchers in your field

- rapid publication on acceptance

- support for research data, including large and complex data types

- gold Open Access which fosters wider collaboration and increased citations

- maximum visibility for your research: over $100 \mathrm{M}$ website views per year

At BMC, research is always in progress.

Learn more biomedcentral.com/submissions 